\title{
Polymorphism of the Ovine Calpastatin (CAST) Gene and its Association with Productive Traits in Nellore Sheep
}

\author{
B. Ramadevi' ${ }^{1}$, B. Punya Kumari ${ }^{2 *}$, K. Sudhakar ${ }^{3}$, G. Gangaraju ${ }^{4}$ and U. Vinod ${ }^{2}$ \\ ${ }^{1}$ Animal Husbandry Polytechnic, Venkataramannagudem, Sri Venkateswara Veterinary University, Andhra Pradesh, INDIA \\ ${ }^{2}$ Department of Animal Genetics and Breeding, College of Veterinary Science, Sri Venkateswara Veterinary University \\ Tirupati- Andhra Pradesh, INDIA \\ ${ }^{3}$ Department of Animal Genetics and Breeding, College of Veterinary Science, Sri Venkateswara Veterinary University, \\ Gannavaram- Andhra Pradesh, INDIA \\ ${ }^{4}$ Livestock Research Station, Palamaner, Chittoor, Andhra Pradesh, INDIA \\ "Corresponding author: B PunyaKumari; E-mail: punya67@yahoo.co.in
}

Received: 12 Oct., 2020

Revised: 06 Nov., 2020

Accepted: 13 Nov., 2020

\begin{abstract}
Calpastatin is a candidate marker for carcass and growth traits. The purpose of this work to study MspI polymorphism in the CAST gene in three strains of Nellore sheep breed viz., Jodipi, Brown and Palla and to find its relation with growth traits. The frequencies of $\mathrm{M}$ and $\mathrm{N}$ alleles in Nellore Jodipi, Nellore Brown and Nellore Palla were 0.83 and $0.17,0.81$ and 0.19 , 0.76 and 0.24 , respectively and genotype frequencies of $\mathrm{MM}, \mathrm{MN}$ and $\mathrm{NN}$ genotypes were found to be $0.68,0.31$ and 0.01 in Nellore Jodipi; 0.64, 0.34 and 0.02 in Nellore Brown and 0.56, 0.40 and 0.04 in Nellore Palla, respectively. The PIC values for Nellore Jodipi, Nellore Brown and Nellore Palla are 0.24, 0.26 and 0.30 respectively, suggesting considerable amount of variation exist in these populations. Diversity estimates $\left(\mathrm{F}_{\mathrm{IS}}\right)$ were negative for the three populations of Nellore sheep i.e., Jodipi $(-0.114)$, Brown (-0.105) and Palla (-0.097) indicating that there is no differentiation among the three populations. The $\chi^{2}$-test values revealed that all the three populations are in Hardy- Weinberg equilibrium. The association between genotypes and body weights revealed significant differences among three genotypes (MM, MN and $\mathrm{NN}$ ) only for birth weight; while non-significant differences were observed among three genotypes for average daily gains.
\end{abstract}

\section{HIGHLIGHTS}

0 PCR RFLP technique was used to study the polymorphism of calpastatin gene in three strains of Nellore sheep.

(0 Polymorphism of calpastatin gene significantly influenced the birth weight but not the average daily gains.

Keywords: Calpastatin, Hardy- Weinberg equilibrium, Msp1 Polymorphism and Nellore sheep

Growth traits, which are economically most important traits in livestock are under the control of multiple genes. Selection of animals with higher growth rate is of great significance to breeders and consumers. Current technologies enable scientists to improve the accuracy and efficiency of traditional selection methods by applying genetic markers through marker- assisted selection. Therefore, genetic polymorphisms that are significantly associated with certain traits of interest are very useful.

Calpastatin is special inhibitor of Calpain that influence rate of muscle extension. It is a candidate marker for growth and carcass traits in livestock. Calpain-Calpastatin system is responsible for the breakdown of myofibrillar protein which is closely related to skeletal muscle growth and wastage and in meat tenderization following slaughter (Fig. 1). The present investigation was aimed at studying the genetic variation at $C A S T$ region in three strains

How to cite this article: Ramadevi1, B., Punya Kumari, B., Sudhakar, K., Gangaraju, G. and Vinod, U. (2020). Polymorphism of the Ovine Calpastatin (CAST) gene and its association with productive traits in Nellore sheep. J. Anim. Res., 10(6): 881-887.

Source of Support: None; Conflict of Interest: None कि क्ष 
of Nellore sheep breed and to assess the possibility of developing a DNA marker system for skeletal muscle growth, since it has been proved that this gene plays a major role in regulating growth traits.

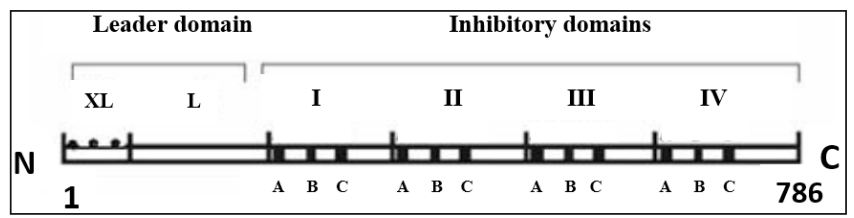

Fig. 1: Structure of Calpastatin's polypeptide domains

The Southern peninsular region of India is home to 14 descriptive sheep breeds, of which Nellore sheep is the tallest and popular mutton breed of Andhra Pradesh. Major population is Nellore Jodipi followed by Brown and Palla. Nellore Jodipi has white coat with black colour on the belly, sides of face, wattles, eyes, below knee, hock and thigh region and contains little hair except at brisket, withers and breech (Fig. 2).

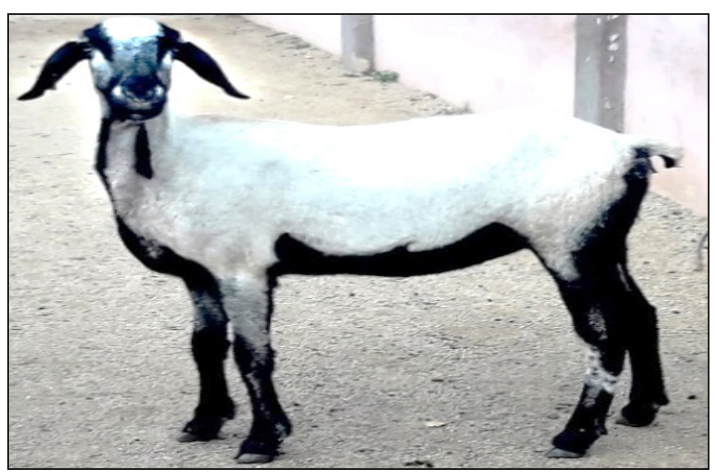

Fig. 2: Nellore Jodipi breed of goat

Nellore Brown is completely brown to red in colour (Fig. 3 ) and Nellore Palla is completely white in colour (Fig. 4).

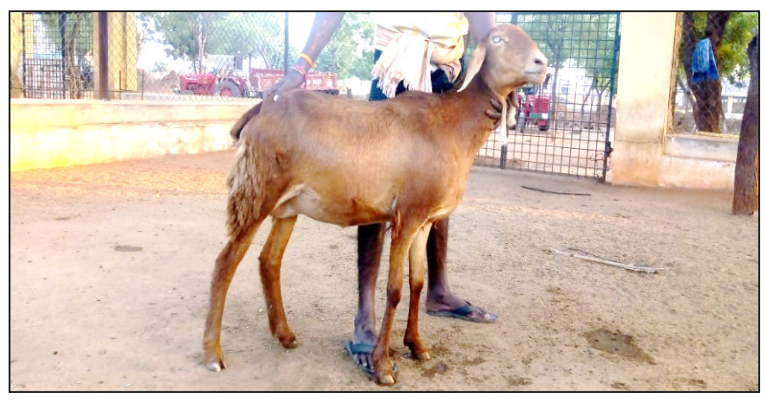

Fig. 3: Nellore Brown breed of goat

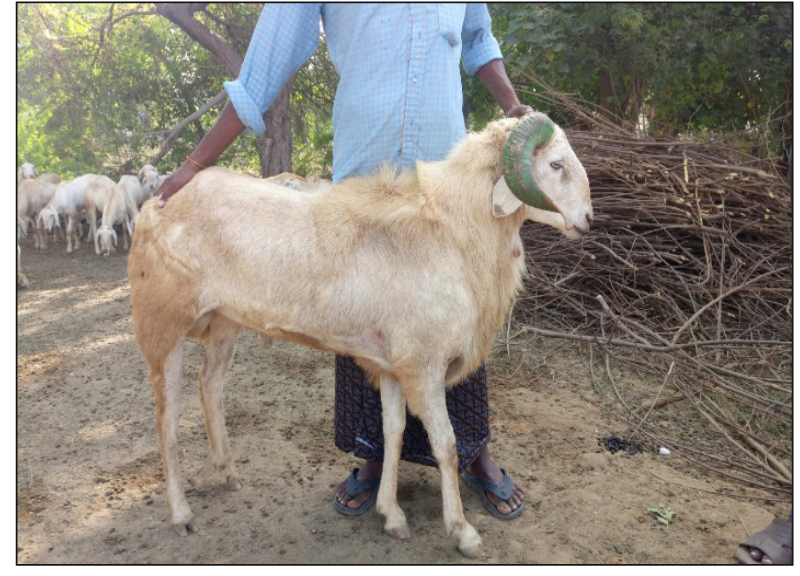

Fig. 4: Nellore Palla breed of goat

Rams are horned and ewes are almost polled. Face is Convex to straight with black muzzle. Ears are long and drooping. Horns vary in size, long, curved. About $80 \%$ of animals have wattles. Height at withers in males vary from 85 to $89 \mathrm{~cm}$. and in females from 80 to $82 \mathrm{~cm}$. Chest girth vary from 84 to $89 \mathrm{~cm}$, while, Paunch girth from 84 to $88 \mathrm{~cm}$ and Body length varies from 75 to $78 \mathrm{~cm}$. Nellore Jodipi distributed throughout the state, but major population found in Nellore, Chittoor and Prakasam districts, whereas, Nellore Brown is distributed in Rayalaseema region. Nellore Palla is limited to Atmakur mandal of Nellore district. Studies on the polymorphism of Calpastatin gene in Nellore breed of sheep are scanty and limited. Hence, the present study is aimed at understanding natural variation of CAST locus in the three strains of Nellore sheep.

\section{MATERIALS AND METHODS}

A total of 180 blood samples were collected from unrelated sheep population, out of which 80 samples from Nellore Jodipi sheep maintained at NWPSI, Livestock Research Station, Palamaner, 50 samples from Nellore Brown sheep maintained at Livestock Research Station, Siddarampuram and 50 samples from Nellore Palla sheep from farmers flocks maintained at Atmakur mandal in Nellore district for isolation of genomic DNA. Phenotypic information on body weights at birth, 3, 6, 9- and 12-months age for the Nellore Jodipi sheep were taken from performance records of the Livestock Research Station, Palamaner and data on adult body weights (more than 2 years of age) of Nellore Brown sheep also collected from the Livestock 
Research Station, Siddarampuram for association studies. The experiment was conducted at the Department of Animal Genetics and Breeding, College of Veterinary Science, Sri Venkateswara Veterinary University, Tirupati from May to December, 2018 (This research work has been approved by the IAEC with reference number 281/ go/ReBi/S/2000/CPCSEA/CVSc/TPTY/009/AGB/201718 dated 05-02-2018.). Genomic DNA was isolated by following the standard protocol involving Proteinase K digestion and Phenol: chloroform extraction (Sambrook et al., 1989) with minor modifications. The quality and purity of DNA was checked by agarose gel electrophoresis and quantification was done by UV spectrophotometer. DNA quantity ranged from $50.7 \mathrm{ng} / \mu \mathrm{l}$ to $3056.4 \mathrm{ng} / \mu \mathrm{l}$ and the optical absorbance ratio (A260/A280) varied from 1.34 to 2.14 .

\section{CAST gene}

Exon and intron region from a portion of the first repetitive domain of the ovine calpastatin gene were amplified to a product of $569 \mathrm{bp}$ using primers based on the sequence of ovine calpastatin genes (Table 1).

\section{Method of detection}

The polymerase chain reaction (PCR) was performed using a $5 \mu \mathrm{l} 2 \mathrm{X}$ PCR master mix, $0.5 \mu \mathrm{l}$ forward primer (10 pmoles), $0.5 \mu \mathrm{l}$ reverse primer (10 pmoles), $1 \mu \mathrm{l}$ ovine genomic DNA (100 ng) and nuclease free water up to a total volume of $10 \mu \mathrm{l}$. Cyclic condition of PCR included one cycle of initial denaturation at $95^{\circ} \mathrm{C}(3 \mathrm{~min})$ followed by thirty-five cycles of denaturation at $95^{\circ} \mathrm{C}$ (15 seconds), annealing at $58^{\circ} \mathrm{C}(40$ seconds), extension at $72^{\circ} \mathrm{C}$ (30 seconds) and one cycle of final extension at $72^{\circ} \mathrm{C}$ (5 min). The PCR products were separated by $2 \%$ $(\mathrm{w} / \mathrm{v})$ agarose gel electrophoresis. The amplified fragment of calpastatin was digested with $M s p$ I enzyme (Table 2). Digestion was conducted at $37^{\circ} \mathrm{C}$ for $12-16 \mathrm{~h}$ and in a 10 $\mu \mathrm{l}$ reaction solution including $5.8 \mu \mathrm{l}$ of distilled $\mathrm{H}_{2} \mathrm{O}, 1 \mu \mathrm{l}$ buffer, $0.2 \mu \mathrm{l}$ ( 2 units) of restriction endonucleases ( $M s p \mathrm{I}$ ), and $3 \mu \mathrm{l}$ of PCR product solution. The resulting digestion products were electrophoretically analysed through $2 \%$ agarose gels stained with ethidium bromide $(10 \mathrm{mg} /$ $\mathrm{ml}$ ) in IX TAE buffer ( $\mathrm{pH}$ 8.0). Molecular size marker (100bp DNA ladder, HIMEDIA ${ }^{\circledR}$ ) was loaded to the last well. The electrophoresis was carried out at 80 volts for 45 minutes. The amplified product was visualized as a single compact fluorescent band of expected size under UV transilluminator and photographed with UVi-tech gel documentation system (THERMO SCIENTIFIC ${ }^{\circledR}$ ). The genotypes were scored based on the presence of a double band (homozygotes) or triple bands (heterozygotes) on the agarose gel slab.

\section{Population genetic analysis}

PCR-RFLP is a bi allelic system and hence, the maximum possible genotypes are three. From the gels the genotypes were scored directly as homozygous or heterozygous. The expected heterozygosity and Polymorphic Information Content (PIC) were calculated using PIC calculator in the Google home page. The polymorphic locus was used to test for equilibrium in each of the population by using Hardy Weinberg calculator (www.dr-petrek.eu). The population differentiation is tested using $\mathrm{F}_{\text {IS }}$ (inbreeding coefficient) values calculated online at http://popsc.chenshiyi.com/ Wright_F st $^{*}$

Table 1: Sequences of primers used for amplification of Calpastatin gene

\begin{tabular}{lll}
\hline Primer & Primer sequence & Expected product size (bp) \\
\hline Forward & CAST F- 5'CCTTGTCATCAGACTTCACC 3' & 565 \\
Reverse & CAST R- 5'ACTGAGCTTTTAAAGCCTCT 3' & \\
\hline
\end{tabular}

Table. 2: Restriction enzyme MspI enzyme digestion for intron 1 fragment of CAST

\begin{tabular}{ll}
\hline Restriction enzymes & Recognition site \\
\hline MspI (Morexella species) & $5^{\prime} \ldots \mathrm{C} \downarrow \mathrm{CGG} \ldots 3^{\prime}$ \\
& $3^{\prime} \ldots \mathrm{GGC} \uparrow \mathrm{C} \ldots 5^{\prime}$ \\
\hline
\end{tabular}




\section{Association studies}

An attempt was made to study the association of genotypes with body weights at birth, 3, 6, 9, 12 months of age and average daily gains in Nellore Jodipi sheep and adult body weights (more than 2 years of age) in Nellore Brown sheep and data is subjected to ANOVA to find out the significant differences among genotypes by using SPSS software 25.0 version.

\section{RESULTS AND DISCUSSION}

\section{CAST gene polymorphism}

A $565 \mathrm{bp}$ fragment of the intron 1 from L domain region of the ovine CAST locus was amplified by PCR using oligonucleotide primers (Fig. 5). The size of amplified product was same for all the strains of Nellore sheep (Jodipi, Brown and Palla) studied, which was in agreement with the findings of Khederzadeh (2011) in crossbreed Dalagh sheep and Ibrahim et al. (2015) in Barki lambs indicating that the $C A S T$ region in sheep is conserved.

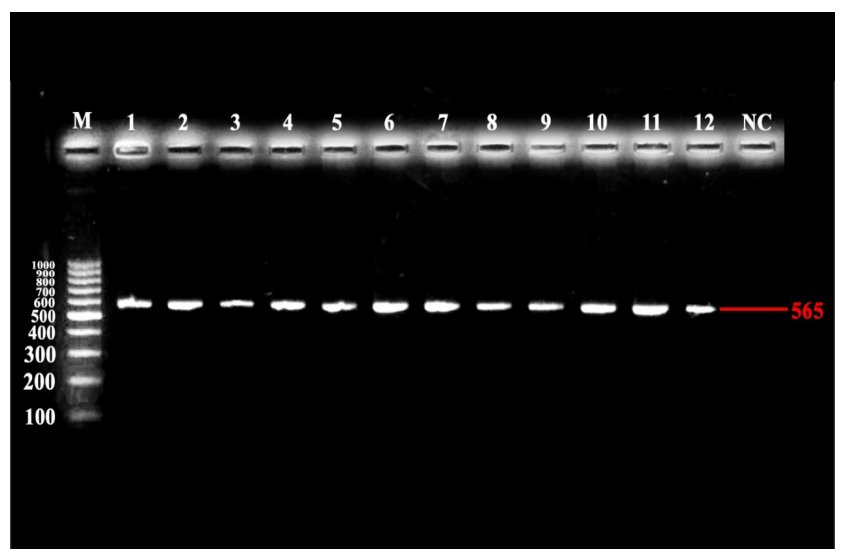

Fig. 5: Amplicons of intron 1 of CAST ovine locus MC: 100 bp marker, Lane 1-4: Nellore Jodipi Samples, Lane 5-8: Nellore Brown samples, Lane 9-12: Nellore Palla samples, NC: Negative control

\section{Restriction patterns}

PCR-RFLP genotyping was used to discover the polymorphism in the region between exons and $565 \mathrm{bp}$ of CAST gene. The amplified $565 \mathrm{bp}$ fragment was restricted into $306 \mathrm{bp}$ and $259 \mathrm{bp}$ fragments when a polymorphic MspI site was present. This allowed the identification of two allele's viz., M (306 and 259 bp fragment) and N (undigested fragment of $565 \mathrm{bp}$ ) (Table 3).

In the present study, two alleles ( $\mathrm{M}$ and $\mathrm{N})$ and three genotypes (MM, MN and NN) were observed for intron 1 region from $\mathrm{L}$ domain of CAST gene in three strains of Nellore sheep viz., Jodipi, Brown, Palla (Fig. 6). Study of polymorphism on the same region of the CAST gene in Dalagh sheep revealed three genotypes $\mathrm{MM}, \mathrm{MN}$ and NN (Khederzadeh, 2011). The polymorphism in the exon 1 of the CAST gene in various sheep breeds similar to present study was also reported by other researchers using PCR-RFLP technique (Suleman et al., 2012 in Kajli, Lohi and Thalli breeds; Yilmaz et al., 2014 in Kivircik (KIV), Sakiz (SZ) and Karacabey Merino (KM); Georgieva et al., 2015 in Synthetic Population of Bulgarian Milk sheep; Saleha, 2015 in Najdi and Harri). Variation in non-coding and coding regions of the ovine CAST gene has been also reported by several researchers (Roberts et al., 1996, Palmer et al., 1998 and Zhou et al., 2007).

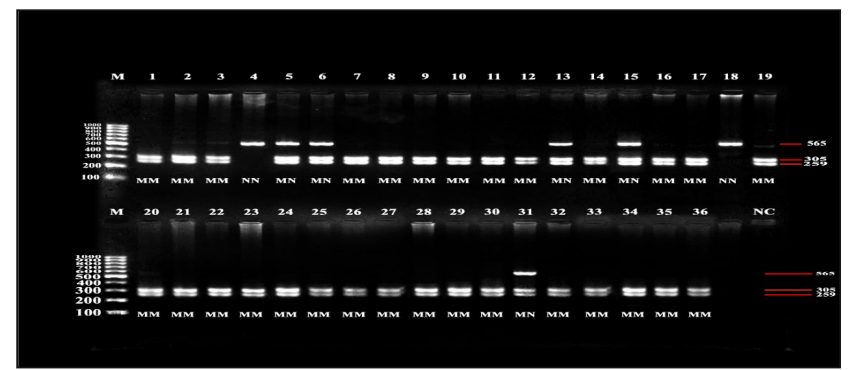

Fig. 6: $C A S T / M s p I$ pattern of 565 bp PCR product; M: 100 bp marker, Lane 1-12: Nellore Jodipi samples, Lane 13-24: Nellore Brown samples, Lane 25-36: Nellore Palla samples, NC: Negative control

Table 3: Allelic pattern, gene and genotypic frequencies of $C A S T$ gene

\begin{tabular}{llllll}
\hline Sl. No. & Allele type & Fragment size (bp) & Number of animals & Genotype frequencies & Gene Frequencies \\
\hline 1. & MM & 306,259 & 114 & 0.63 & $\mathrm{M}=0.81$ \\
2. & MN & $565,306,259$ & 62 & 0.35 & $\mathrm{~N}=0.19$ \\
3. & NN & 565 & 4 & 0.02 & \\
\hline
\end{tabular}




\section{Population analysis}

The allelic frequencies of $\mathrm{M}$ and $\mathrm{N}$ alleles in Nellore Jodipi, Nellore Brown and Nellore Palla are 0.83 and 0.17 , 0.81 and $0.19,0.76$ and 0.24 , respectively. The frequency of the MM genotypes in three strains i.e. Nellore Jodipi, Nellore Brown and Nellore Palla was found to be 0.68 , 0.64 and 0.56 , respectively. The observed frequency of the MN genotype was $0.31,0.34$ and 0.4 and the frequency of $\mathrm{NN}$ genotype was $0.01,0.02$ and 0.04 in three strains, respectively (Table 4 ). The obtained results almost coincided with those of Khederzadeh (2011), who, observed frequencies of $0.66,0.29$ and 0.06 for the $\mathrm{MM}, \mathrm{MN}$ and NN genotypes in cross bred Dalagh sheep, respectively.

The frequency of $\mathrm{M}$ allele $(0.81)$ is more than the $\mathrm{N}$ allele (0.19) in three strains of Nellore sheep. Similar to present findings, Eftekhari et al. (2006) reported that the frequencies of $\mathrm{M}$ and $\mathrm{N}$ alleles of $C A S T$ gene digested with MspI in Karakul sheep were 0.79 and 0.21 , respectively. Gabor et al. (2009) also reported the genotyping results of $C A S T$ gene locus digested with $M s p$ I enzyme in Tsigai sheep as 0.91 and 0.09 , Improved Valachian as 0.97 and 0.03 , and Tsigai sheep $\times$ Lacaune cross bred sheep as 0.90 and 0.10 for $\mathrm{M}$ and $\mathrm{N}$, respectively. In addition, Suleman et al. (2012) found that the frequency of $\mathrm{M}$ allele was higher than that of $\mathrm{N}$ allele in Thalli (0.9 and 0.1), Lohi (0.87 and 0.13) and Kajli (0.81 and 0.19) Pakistan sheep breeds. In contrast to results of the current study, Sumantri et al. (2014) reported that the allele frequency of $\mathrm{N}$ was higher than allele $\mathrm{M}$ in Indonesian Jonggol sheep breed. The highest genotypic frequency $\mathrm{MN}$ was found in Nellore Brown (0.34), MM in Nellore Jodipi (0.68) and NN in Nellore Palla (0.04).

The values of expected heterozygosity for Nellore Jodipi (0.28), Nellore Brown (0.31) and Nellore Palla (0.36) are lower than observed heterozygosity, indicating there is considerable amount of variation exist in these populations. Similarly, Gabor et al. (2009) in Tsigai breed (0.17 and 0.16), Saeed-ul-Hassan et al. (2012) in Balkhi sheep (0.21 and 0.25) and Saleha (2015) in Najdi (0.64 and 0.42 ) and Harri (0.26 and 0.20$)$ breeds reported high observed heterozygosity than expected heterozygosity. PIC values for Nellore Jodipi, Nellore Brown and Nellore Palla are $0.24,0.26$ and 0.30 , respectively indicating that the marker is informative. The $\mathrm{F}_{\text {IS }}$ values observed in this study are negative in three populations of Nellore sheep viz., Jodipi (-0.114), Brown (-0.105) and Palla (-0.097), respectively, which indicates that individuals in three populations are less related to each other. Chi- square test revealed that the three populations of Nellore sheep i.e., Jodipi (1.038), Brown (0.547), Palla (0.466) are in HardyWeinberg equilibrium, which are in concordance with the findings of Eftekhari et al. (2006) in Iranian Karakul sheep (0.61), Azari et al. (2012) in Native Dalagh sheep (5.908) and Suleman et al. (2012) in Thalli (1.23), Lohi (1.336) and Kajli (2.39) breeds.

\section{Association Studies}

\section{Association of CAST polymorphism with mean body weights in Nellore Jodipi sheep}

The mean body weights $(\mathrm{kg})$ varied from $1.80(\mathrm{NN})$ to 3.12 (MM) at birth, $13.00(\mathrm{NN})$ to 15.34 (MM) at 3 months, $21.66(\mathrm{MM})$ to $22.56(\mathrm{MN})$ at 6 months, $23.20(\mathrm{NN})$ to $27.28(\mathrm{MN})$ at 9 months and $28.10(\mathrm{MM})$ to $29.81(\mathrm{MN})$ at 12 months of age (Table 5). Genotype MN recorded highest body weights at majority of ages.

However, non-significant differences were observed among genotypes for mean body weights $(\mathrm{P}>0.05)$ at

Table 4: Gene and genotypic frequencies of CAST/MspI polymorphism and observed and expected heterozygosity, PIC values, chisquare values and Wrights $F_{\text {is }}$ in three strains of Nellore sheep

\begin{tabular}{|c|c|c|c|c|c|c|c|c|c|c|c|c|}
\hline \multirow{2}{*}{ Sl. No. } & \multirow{2}{*}{ Population } & \multirow{2}{*}{$\mathbf{n}$} & \multicolumn{3}{|c|}{ Genotypes } & \multirow{2}{*}{$M\left(n^{\prime}\right)$} & \multirow{2}{*}{$\mathbf{N}\left(\mathbf{n}^{\prime}\right)$} & \multirow{2}{*}{$\mathbf{H}_{\mathrm{o}}$} & \multirow{2}{*}{$\mathbf{H}_{\mathrm{e}}$} & \multirow{2}{*}{ PIC } & \multirow{2}{*}{$\begin{array}{l}\text { Chisquare } \\
\text { value }\end{array}$} & \multirow{2}{*}{$\mathbf{F}_{\text {IS }}$} \\
\hline & & & MM (n) & MN (n) & NN (n) & & & & & & & \\
\hline 1 & Nellore Jodipi & 80 & $0.68(54)$ & $0.31(25)$ & $0.01(1)$ & $0.83(133)$ & $0.17(27)$ & 0.31 & 0.28 & 0.24 & 1.038 & -0.114 \\
\hline 2 & Nellore Brown & 50 & $0.64(32)$ & $0.34(17)$ & $0.02(1)$ & $0.81(81)$ & $0.19(19)$ & 0.34 & 0.31 & 0.26 & 0.547 & -0.105 \\
\hline 3 & Nellore Palla & 50 & $0.56(28)$ & $0.40(20)$ & $0.04(2)$ & $0.76(76)$ & $0.24(24)$ & 0.40 & 0.36 & 0.30 & 0.466 & -0.097 \\
\hline
\end{tabular}

$\mathrm{n}=$ number of animals showing particular genotype; $\mathrm{n}=$ no. of alleles. 
Table 5: Mean body weights $(\mathrm{kg})$ in different genotypes of CAST gene in Nellore Jodipi sheep

\begin{tabular}{|c|c|c|c|c|c|c|c|c|}
\hline \multirow{3}{*}{ B.wt } & \multicolumn{8}{|c|}{ Genotypes } \\
\hline & \multirow{2}{*}{ MM $(n=54)$} & \multirow{2}{*}{ MN (n=25) } & \multirow{2}{*}{ NN $(n=1)$} & \multicolumn{2}{|c|}{ Males $(n=27)$} & \multicolumn{3}{|c|}{ Females $(n=53)$} \\
\hline & & & & MM (n=15) & MN (n=12) & MM $(n=39)$ & MN (n=13) & $\mathbf{N N}(n=1)$ \\
\hline Birth & $3.12 \pm 0.05^{\mathrm{a}}$ & $3.08 \pm 0.10^{\mathrm{b}}$ & $1.80^{\mathrm{c}}$ & $3.14 \pm 0.11^{\mathrm{a}}$ & $3.17 \pm 0.13^{\mathrm{a}}$ & $3.11 \pm 0.56^{\mathrm{a}}$ & $2.99 \pm 0.17^{\mathrm{b}}$ & $1.80^{\mathrm{c}}$ \\
\hline 3 months & $15.34 \pm 0.45^{\mathrm{a}}$ & $15.03 \pm 0.73^{\mathrm{a}}$ & $13.00^{\mathrm{a}}$ & $16.47 \pm 0.96^{\mathrm{a}}$ & $15.07 \pm 1.20^{\mathrm{a}}$ & $14.91 \pm 0.50^{\mathrm{a}}$ & $14.99 \pm 0.90^{\mathrm{a}}$ & $13.00^{\mathrm{a}}$ \\
\hline 6 months & $21.66 \pm 0.58^{\mathrm{a}}$ & $22.56 \pm 0.94^{\mathrm{a}}$ & $22.00^{\mathrm{a}}$ & $23.73 \pm 1.16^{\mathrm{a}}$ & $23.62 \pm 1.55^{\mathrm{a}}$ & $20.87 \pm 0.64^{\mathrm{a}}$ & $21.59 \pm 1.09^{\mathrm{a}}$ & $22.00^{\mathrm{a}}$ \\
\hline 9 months & $25.92 \pm 0.52^{\mathrm{a}}$ & $27.28 \pm 0.67^{\mathrm{a}}$ & $23.20^{\mathrm{a}}$ & $28.85 \pm 0.79^{\mathrm{a}}$ & $28.59 \pm 0.98^{\mathrm{a}}$ & $24.79 \pm 0.55^{\mathrm{a}}$ & $26.08 \pm 0.82^{\mathrm{a}}$ & $23.20^{\mathrm{a}}$ \\
\hline 12 months & $28.10 \pm 0.52^{a}$ & $29.81 \pm 0.66^{\mathrm{a}}$ & $29.80^{\mathrm{a}}$ & $31.11 \pm 0.59^{\mathrm{a}}$ & $31.23 \pm 1.03^{a}$ & $26.95 \pm 0.58^{a}$ & $28.50 \pm 0.69^{\mathrm{a}}$ & $29.80^{\mathrm{a}}$ \\
\hline
\end{tabular}

Means with same superscripts in each row do not differ significantly $(\mathrm{P}>0.05)$.

all ages except at birth weight $(\mathrm{P}<0.05)$. The present findings coincided with Nassiry et al. (2006); Sutikno et al. (2011) and Nikmard et al. (2012), who, also reported non-significant differences among the three genotypes for bodyweights in Kurdi, Jonggol and Afshari sheep Breeds, respectively. In contrast, Sumantri et al, (2014) indicated positive correlations between body weights and Calpastatin genotypes.

Only two genotypes (MM and $\mathrm{MN}$ ) were identified in males. Even though, MM recorded higher body weights compared to $\mathrm{MN}$ genotype, but the differences failed to reach significant level at all ages. In females all three genotypes $\mathrm{MM}, \mathrm{MN}$ and $\mathrm{NN}$ were expressed. Mean body weight at birth was high in MM genotype $(3.11 \mathrm{~kg}$ ) compared to other two genotypes $\mathrm{MN}(2.99 \mathrm{~kg})$ and $\mathrm{NN}$ $(1.80 \mathrm{~kg})$. Genotype MN (14.99 and $26.08 \mathrm{~kg}$ ) showed high mean body weight followed by MM (14.91 and 24.79 $\mathrm{kg}$ ) and $\mathrm{NN}(13.00$ and $23.20 \mathrm{~kg}$ ) at 3 and 9 months of age. However, at 6 and 12 months of age, highest mean body weights were noticed in $\mathrm{NN}(22.00$ and $29.80 \mathrm{~kg})$ genotype than $\mathrm{MN}(21.59$ and $28.50 \mathrm{~kg})$ and $\mathrm{MM}(20.87$ and $26.95 \mathrm{~kg}$ ), respectively. Sumantri et al. (2014) reported an association between Calpastatin gene and body weights in male sheep of Indonesia, and revealed that Male lambs of MN genotype were significantly higher in body weight than male lambs that had the NN genotypes.

\section{Association of $C A S T$ polymorphism with average daily gains in Nellore Jodipi}

The mean average daily gain (Table 6) from birth to 3 months (ADG 1) of age was highest in all three MM (135.82 g), MN (132.80 g) and NN (124.44 g) genotypes. The least mean values were recorded from 9 to 12 months
(ADG 4) of age in MM (24.30 g) and MN (28.04 g) genotypes but in case of $\mathrm{NN}$ (13.33 g) genotype from 6 to 9 months (ADG 3 ) of age showed least.

Mean average daily gains (Table 7) of genotypes MM and $\mathrm{MN}$ in males exhibited high average daily gains from birth to weaning (ADG 1) as 148.07 and $132.22 \mathrm{~g}$, respectively. The lowest means are recorded from 9 to 12 months (ADG 4) of age as 25.11 and 29.26 g, respectively. However, nonsignificant differences $(\mathrm{P}>0.05)$ were observed between mean average daily gains among two genotypes at all age intervals.

Highest mean values for the average daily gains recorded from birth to 3 months (ADG 1) in MM (131.11 g), MN $(133.33 \mathrm{~g})$ and $\mathrm{NN}(124.44 \mathrm{~g})$ genotypes in females. Lowest mean values recorded from 9 to 12 months of age in MM (23.99 g) and MN (29.26 g) genotypes; while, NN genotype recorded least mean average daily gains from 6 to 9 months (ADG 3) of age. Non-significant differences $(\mathrm{P}>0.05)$ between mean average daily gains was observed irrespective of genotype and age. Whereas, Chung and Davis (2012) reported that AA (222.00 g) genotype significantly gained more daily weights than the other two genotypes AB (217.00 g) and BB (201.00 g), while, Tahmoorespour (2005) reported a positive effect of the heterozygous genotype on the average daily gains in Kurdi and Baluchi sheep.

\section{Association of CAST polymorphism with growth traits in Nellore Brown sheep}

Mean body weights of adult Nellore Brown sheep ( $>2$ years) was high in NN genotype $(36.00 \mathrm{~kg})$ followed by $\mathrm{MN}(32.62 \mathrm{~kg})$ and MM (32.30 kg) genotypes. However, non-significant differences observed between body 
weights among the three genotypes in the present study coincided with results of Chung and Davis (2012).

\section{CONCLUSION}

The size of amplified product was same (565 bp) for all the three strains of Nellore sheep. The amplified $565 \mathrm{bp}$ fragment was restricted into $306 \mathrm{bp}$ and $259 \mathrm{bp}$ fragments when a polymorphic $M s p$ I site was present and resulted in $\mathrm{MM}, \mathrm{MN}$, and NN genotypes. Association studies of genotypes with body weights and average daily gains revealed non-significant association except for birth weight. Further, in the present study, the number of records taken for association studies is limited in Nellore Jodipi (80) and Nellore Brown (50). The observations under NN genotype is only one in both Nellore Jodipi and Brown sheep which might be one of the reasons to obtain nonsignificant variation among genotypes. Hence, this study further has to be extended to large sample size to draw the valid conclusions about the association between $C A S T$ gene polymorphism and growth traits.

\section{REFERENCES}

Azari, M.A., Dehnavi, E., Yousefi, S. and Shahmohamadi, L. 2012. Polymorphism of calpastatin, calpain and myostatin genes in native dalagh sheep in Iran. Slovak J. of Anim. Sci., 45: 1-6.

Chung, H. and Davis, M. 2012. PCR-RFLP of the ovine Calpastatin gene and its association with growth. Asian $J$. Anim. Vet. Adv., 7: 641-652.

Eftekhari, S.F., Nassiri, M., Valizadeh, R., Heravi, M.A., Tahmoorespur, M. and Ghiasi, H. 2006. Genetic polymorphism at MTNR1A, CAST and CAPN loci in Iranian Kurakul sheep. Iranian J. Biotech., 4: 117-122.

Gabor, M., Trakovická, A. and Miluchová, M. 2009. Analysis of polymorphism of CAST gene and CLPG gene in sheep by PCR-RFLP method. Luc. Stiint. Zooteh. Biotehnol., 42(2): 470-476.

Georgieva, S., Hristova, D., Dimitrova, I., Stancheva, N. and Bozhilova, S.M. 2015. Molecular analysis of ovine calpastatin (CAST) and myostatin (MSTN) genes in Synthetic Population Bulgarian Milk sheep using PCR RFLP. J. Bio. Sci. Biotech., 4(1): 95-99.

Ibrahim, A.H.M., Ismail, I.M., Shehata, M.F. and El-Beltagy, A.R. 2015. Calpastatin Polymorphism in Barki Lambs and their Effects on Growth and Carcass Traits. J. Am. Sci., 11(3): 106-112.

Khederzadeh, S. 2011. Polymorphism of calpastatin gene in crossbreed Dalagh sheep using PCR-RFLP. Afr. J. Biotech., 10(53): 10839-10841.
Nassiry, M.R., Tahmoorespour, M., Javadmanesh, A., Soltani, M. and Foroutani, F.S. 2006. Calpastatin polymorphism and its association with daily gain in Kurdi sheep. Iranian $J$. Biotechnology., 4(3): 188-192.

Nikmard, M., Molaee, V., Eskandarinasab, M.P., Dinparast Djadid, N. and Vajhi, A. R. 2012. Calpastatin polymorphism in Afshari sheep and its possible correlation with growth and carcass traits. J. Appl. Anim. Res., 40(4): 346-350.

Palmer, B.R., Roberts, N. and Kent, M.P. 1999. A candidate gene approach to animal quality traits. Proc. NZ. Society. Anim. Prod., 57: 294-296.

Roberts, N., Palmer, B., Hickford, J.G. and Bickerstaffe, R. 1996. PCR-SSCP in the ovine Calpastatin gene. Anim. Genet., 27(3): 211.

Saeed-ul-Hassan, K., Riaz, M. N., Ghaffar, A. and Khan, M. F. U. 2012. Calpastatin (CAST) gene polymorphism and its association with average daily weight gain in Balkhi and Kajli sheep and Beetal goat breeds. Pakistan J. Zool., 44(2): 377-382.

Saleha, Y. M. and Alakilli. 2015. Analysis of Polymorphism of Caplstatin and Callipyge Genes in Saudi Sheep Breeds Using PCR-RFLP Technique. Int. J. Pharm. Sci. Rev. Res., 30(1): 340-344.

Sambrook, J., Fristch, E. and Maniatis, T. 1989. Molecular cloning. Laboratory Manual. Cold Spring Harbour Laboratory Press, Cold Spring Harbour, New York.

Suleman, M., Khan, S.U., Riaz, M.N., Yousaf, M., Shah, A. and Ishaq, R. 2012. Calpastatin (CAST) gene polymorphism in Kajli, Lohi and Thalli sheep breeds. Afr. J. Biotech., 11(47): 10655-10660.

Sumantri, C., Diyono, R., Farajallah, A. and Inounu, I. 2014. Polymorphism of Calpastatin gene and its effect on body weight of local sheep. JITV., 13(2): 117-26.

Sutikno, S., Yamin, M. and Sumantri, C. 2011. Association of polymorphisms of Calpastatin gene with body weight of local sheep in Jonggol, Indonesia. Media Peternakan: J. Anim. Sci. Tech., 34(1): 1-6.

Tahmoorespour, M. 2005. Study on the calpain and calpastatin gene polymorphisms by polymerase chain reaction - single strand conformation polymorphism and its relation to average daily gain in Iranian Baluchi sheep. Ph.D., Thesis, Ferdowsi University, Mashhad, Iran.

Yilmaz, O., Sezenler, T., Ata, N., Yaman, Y., Cemal, I. and Karaca, O. 2014. Polymorphism of the ovine Calpastatin gene in some Turkish sheep breeds. Turkish J. Vet. Anim. Sci., 38(4): 354-357.

Zhou, H., Hickford, J.G.H. and Gong, H. 2007. Polymorphism of the ovine Calpastatin gene. Mol. Cell. Probes., 21(3): 242 244. 
